\title{
The Relationship between Blood Thyroid Hormone and Dopamine Levels in Residents of the Arctic Regions of Russia
}

\author{
Elena V. Tipisova, $\mathrm{PhD}, \mathrm{ScD}^{1 *}$; Irina N. Gorenko ${ }^{1}$; Victoria A. Popkova, $\mathrm{PhD}^{1}$; Alexandra \\ E. Elfimova, $\mathrm{PhD}^{1}$; Dmitry S. Potutkin ${ }^{1}$; Sergey V. Andronov, $\mathrm{PhD}^{2}$; Ruslan A. Kochkin ${ }^{2}$; \\ Andrei I. Popov, $\mathrm{PhD}^{2}$; Andrei A. Lobanov, $\mathrm{PhD}, \mathrm{ScD}^{2}$; Elena N. Bogdanova, $\mathrm{PhD}^{3}$ \\ ${ }^{I} N$. Laverov Federal Center for Integrated Arctic Research, Arkhangelsk, Russia \\ ${ }^{2}$ Scientific center of Arctic research, Salekhard, Russia \\ ${ }^{3}$ Northern (Arctic) Federal University named after M.V. Lomonosov, Arkhangelsk, Russia
}

\begin{abstract}
Due to the presence of contradictory results about the effect of dopamine on the synthesis and secretion of thyroid hormones, as well as the absence of this information in clinically healthy individuals, we were interested in studying this problem in permanent residents of the Arctic territories, which are characterized by high thyroid activity and dopamine content. The aim of this work was to study the hormone levels of hypothalamic-pituitary-thyroid axis (HPTA) under the different levels of dopamine in the blood of permanent residents of the Arctic territories.

Materials and Methods: We examined 316 healthy individuals (the indigenous population, mestizos, and the local Russian population) born and permanently residing in the territories of the Russian Arctic zone. The examined participants were divided into 3 groups: Group 1 with undetectable levels of dopamine in the blood $(0 \mathrm{nmol} / \mathrm{l})$; Group 2 with reference levels of dopamine $(<0.653 \mathrm{nmol} / \mathrm{l})$; and Group 3 with increased levels of dopamine $(>0.653 \mathrm{nmol} / \mathrm{l})$. The serum levels of TSH, T4, free T4, T3, and free $\mathrm{T} 3$, and the plasma dopamine level were determined by enzyme immunoassay. The plasma cAMP level was determined by radioimmunoassay.

Results: In individuals of Group 1, there was a decrease in the activity of hypothalamic-pituitary-thyroid axis (HTPA) and the peripheral conversion of iodothyronines compared with persons with reference or increased dopamine levels. In individuals of Groups 2 and 3, we found an increase in the activity of HTPA with an increase in the blood level of dopamine. The absence of the inhibitory effect of high levels of dopamine on HPTA hormones in the examined individuals may be a compensatoryadaptive response of the body under the conditions of permanently acting extreme factors of the North. (International Journal of Biomedicine. 2019;9(1):43-47.)
\end{abstract}

Key Words: dopamine $\bullet$ iodothyronines $\bullet$ cyclic adenosine monophosphate $\bullet$ Arctic

\section{Abbreviations}

cAMP, cyclic adenosine monophosphate; HPTA, hypothalamic-pituitary-thyroid axis; TSH, thyroid stimulating hormone; T4, thyroxine; T3, triiodothyronine; fT3, free T3; fT4, free T4.

\section{Introduction}

Numerous studies have shown that the activity of the sympathoadrenal system increases under adaptation of the

*Corresponding author: Elena V. Tipisova, PhD, ScD. N. Laverov Federal Center for Integrated Arctic Research, Arkhangelsk, Russia.E-mail: tipisova@rambler.ru body to the cold, which is especially important for people living in extreme conditions of high latitudes. ${ }^{(1,2)}$ Thus, K. Harinath and colleagues ${ }^{(2)}$ studied the role of the autonomic nervous system and adrenal system in acclimatization to cold in tropical men during short or prolonged sojourns at Antarctica. The study was carried out on volunteers of the winter over team (WOT) and summer team (ST) of an Indian Antarctic Expedition. This study suggested that Antarctic residency during austral summer 
resulted in gradual attenuation of sympathetic tone and a shift of autonomic balance toward the parasympathetic side. However, WOT members showed a predominance of sympathetic and adrenal activity compared with initial responses of ST members, suggesting deconditioning or possible resetting of the autonomic nervous system.

Most studies indicate the presence of a dopamine inhibitory effect on the secretion of thyroid hormones by changing the secretion of thyroliberin through the D2 receptors in the striatum, or on the secretion of TSH through the D2 receptors of thyrotropic cells, or by activating the dopamine receptors of thyroid cells. ${ }^{(3-7)}$ Information about the stimulating effects of catecholamines, especially dopamine, on the synthesis of iodothyronines in modern literature is not enough, ${ }^{(8)}$ although early studies have shown the direct stimulating effect of both sympathetic stimuli and exogenous catecholamines, including dopamine, on the synthesis and secretion of iodothyronines. ${ }^{(9)}$

Due to the presence of contradictory results about the effect of dopamine on the synthesis and secretion of thyroid hormones, as well as the absence of this information in clinically healthy individuals, we were interested in studying this problem in permanent residents of the Arctic territories, which are characterized by high thyroid activity and dopamine content. ${ }^{(10)}$ Elucidation of the relationship between dopamine levels and the HPTA activity in the inhabitants of the Arctic territories will contribute to the development of human ecological physiology, as well as preventive medicine, to preserve the health of the population of the North.

The aim of this work was to study the hormone levels of HPTA under the different levels of dopamine in the blood of permanent residents of the Arctic territories.

\section{Materials and Methods}

An analytical cross-sectional uncontrolled study was conducted in the territories of the Russian Arctic zone in the period of increasing daylight hours (March). We examined permanent residents (110 men and 206 women between 22 and 65 years): the indigenous population (the Nenets and the Komi), mestizos, and the local Russian population that had been living in the North for at least 3 generations. The examined participants were divided into 3 groups: Group 1 included 11 men and 45 women with undetectable levels of dopamine in the blood $(0 \mathrm{nmol} / \mathrm{l})$; Group 2 included 70 men and 128 women with reference levels of dopamine $(<0.653$ nmol/1); and Group 3 included 29 men and 33 women with increased levels of dopamine $(>0.653 \mathrm{nmol} / \mathrm{l})$. The mean age of subjects in groups was $45.4 \pm 1.5,45.5 \pm 0.9$ and $45.1 \pm 1.5$ years, respectively. At the time of the survey, subjects did not have a registered endocrine pathology and exacerbations of chronic diseases.

The study was conducted in accordance with the ethical principles stated in Declaration of Helsinki of 1964 (revised in Seoul in 2008). The study was approved by the Ethics Committee of N. Laverov Federal Center for Integrated Arctic Research. Written informed consent was obtained from all participants.
Blood samples $(5 \mathrm{ml})$ were obtained from the ulnar vein on an empty stomach between 8:00 and 10.00 a.m. in IMPROVACUTER' Evacuated Blood Collection Tubes. On 1-plate fully automated ELISA analyzer (Elisys Uno, Germany), the serum levels of TSH, T4, fT4, T3, and fT3 (using test kits from Alkor-Bio, Russia), and the plasma dopamine level (using test kits from LDN, Germany), were determined by enzyme immunoassay. The plasma cAMP level was determined by radioimmunoassay on the ARIAN device (Vitaco, Russia) using RIA kits "Immunotech" (Czech Republic).

Statistical analysis was performed using the statistical software «STATISTICA 10». The normality of distribution of continuous variables was tested by Shapiro-Wilk's W test. Median (Me), the 95\% confidence interval (95\% CI), and percentage deviations from reference value were calculated. Spearman's rank correlation coefficient $\left(r_{s}\right)$ was calculated to measure the strength and direction of the relationship between two variables. A probability value of $P<0.05$ was considered statistically significant.

\section{Results}

Most of the examined individuals, both men and women, had dopamine levels within the reference values $(64 \%$ and $62 \%$, respectively). Undetectable levels of dopamine were recorded twice as often in women than in men $(22 \%$ versus $10 \%$, respectively, $P=0.01$ ).

The increased levels of dopamine were detected in $26 \%$ of men and $16 \%$ of women. Analyzing the content of the HPTA hormones in the examined individuals with different concentrations of blood dopamine (Table 1), we found that both men and women of Group 1, compared to other groups, were characterized by minimum levels of TSH, T4, fT3, cAMP, and the fT3/fT4 ratio against the background of the maximum levels of fT4. A decrease in cAMP levels was especially pronounced. Thus, cAMP levels were lower than the normative levels in $57 \%$ of men and $61 \%$ of women of Group 1.

In persons of Group 2, the levels of TSH, T4, fT3, cAMP, and the fT3/fT4 ratio were higher, and the fT4 level was lower compared to Group 1. Interesting features were noted regarding the cAMP content in Group 2, taking into account the gender aspect. It turned out that the percentage of people with low cAMP levels was higher among women than among men $(27 \%$ and $12 \%, P=0.042)$. At the same time, the levels of thyroid hormones, TSH and cAMP did not significantly differ in Groups 2 and 3, with the exception of the fT3/fT4 ratio. The analysis showed a statistically significant increase in the fT3/ fT4 ratio, with increasing dopamine values in both men and women.

In Group 3, regardless of gender, we found an increase in the proportion of individuals with elevated values of fT3 and cAMP, compared with Group 2, (25\% versus 13\% and $18 \%$ versus $3 \%$, respectively, $P<0.05$ in both cases). Correlation analysis revealed the presence of a significant negative relationship between increased levels of dopamine and fT4 levels in women $\left(\mathrm{r}_{s}=-0.427 ; P=0.019\right)$. 
Table 1.

The content of the HPTA hormones and cAMP in the examined individuals with different concentrations of blood dopamine

\begin{tabular}{|c|c|c|c|c|c|c|c|}
\hline \multirow{4}{*}{ Variable } & \multicolumn{3}{|c|}{ Men } & \multicolumn{3}{|c|}{ Women } & \multirow{4}{*}{$P$-value } \\
\hline & Group 1 & Group 2 & Group 3 & Group 1 & Group 2 & Group 3 & \\
\hline & $\begin{array}{c}\mathrm{Me} \\
95 \% \mathrm{CI}\end{array}$ & $\begin{array}{c}\mathrm{Me} \\
95 \% \mathrm{CI}\end{array}$ & $\begin{array}{c}\mathrm{Me} \\
95 \% \mathrm{CI}\end{array}$ & $\begin{array}{c}\mathrm{Me} \\
95 \% \mathrm{CI}\end{array}$ & $\begin{array}{c}\mathrm{Me} \\
95 \% \mathrm{CI}\end{array}$ & $\begin{array}{c}\mathrm{Me} \\
95 \% \mathrm{CI}\end{array}$ & \\
\hline & 1 & 2 & 3 & 4 & 5 & 6 & \\
\hline $\begin{array}{l}\text { Dopamine, } \\
\mathrm{nmol} / 1\end{array}$ & $\begin{array}{c}0 \\
(0 ; 0)\end{array}$ & $\begin{array}{c}0.43 \\
(0.37 ; 0.46)\end{array}$ & $\begin{array}{c}0.77 \\
(0.74 ; 0.88)\end{array}$ & $\begin{array}{c}0 \\
(0 ; 0)\end{array}$ & $\begin{array}{c}0.36 \\
(0.33 ; 0.41)\end{array}$ & $\begin{array}{c}0.78 \\
(0.75 ; 0.89)\end{array}$ & $\begin{array}{l}\mathrm{P}_{1-2 ; 1-1 ; 2 ; 2-3}<0.001 \\
\mathrm{P}_{45 ; 46 ; 56}<0.001\end{array}$ \\
\hline $\begin{array}{l}\text { TSH, } \\
\mu \mathrm{IU} / 1\end{array}$ & $\begin{array}{c}1.2 \\
(0.9 ; 2.4)\end{array}$ & $\begin{array}{c}2.0 \\
(1.7 ; 2.4)\end{array}$ & $\begin{array}{c}2.2 \\
(1.6 ; 2.7)\end{array}$ & $\begin{array}{c}1.6 \\
(1.3 ; 2.1)\end{array}$ & $\begin{array}{c}2.5 \\
(2.1 ; 2.9)\end{array}$ & $\begin{array}{c}2.3 \\
(1.5 ; 2.5)\end{array}$ & $\begin{array}{l}\mathrm{P}_{1-3}=0.041 \\
\mathrm{P}_{45}=0.006\end{array}$ \\
\hline $\begin{array}{l}\mathrm{T} 4, \\
\mathrm{nmol} / 1\end{array}$ & $\begin{array}{c}79.7 \\
(74.6 ; 105.7)\end{array}$ & $\begin{array}{c}104.2 \\
(96.7 ; 113.2)\end{array}$ & $\begin{array}{c}105.3 \\
(93.1 ; 112.3)\end{array}$ & $\begin{array}{c}105.9 \\
(101.6 ; 110.4)\end{array}$ & $\begin{array}{c}107.5 \\
(105.2 ; 110.6)\end{array}$ & $\begin{array}{c}113.3 \\
(108.5 ; 122.7)\end{array}$ & $\begin{array}{l}\mathrm{P}_{1-2}=0.039 ; \mathrm{P}_{1-3}=0.022 \\
\mathrm{P}_{46}=0.045 ; \mathrm{P}_{1-3}=0.034 \\
\mathrm{P}_{2-5}=0.044 ; \mathrm{P}_{3-6}=0.040\end{array}$ \\
\hline $\begin{array}{l}\mathrm{fT} 4, \\
\mathrm{pmol} / 1\end{array}$ & $\begin{array}{c}15.5 \\
(12.5 ; 18.7) \\
\end{array}$ & $\begin{array}{c}14.5 \\
(13.6 ; 15.4) \\
\end{array}$ & $\begin{array}{c}13.7 \\
(12.8 ; 15.2) \\
\end{array}$ & $\begin{array}{c}15.2 \\
(14.5 ; 16.5) \\
\end{array}$ & $\begin{array}{c}14.3 \\
(13.8 ; 14.7) \\
\end{array}$ & $\begin{array}{c}13.5 \\
(12.8 ; 14.3) \\
\end{array}$ & $\begin{array}{l}\mathrm{P}_{45}=0.002 \\
\mathrm{P}_{46}=0.003\end{array}$ \\
\hline $\begin{array}{l}\mathrm{T} 3, \\
\mathrm{nmol} / 1\end{array}$ & $\begin{array}{c}1.5 \\
(1.3 ; 1.9)\end{array}$ & $\begin{array}{c}1.7 \\
(1.5 ; 1.8)\end{array}$ & $\begin{array}{c}1.6 \\
(1.3 ; 1.8)\end{array}$ & $\begin{array}{c}1.7 \\
(1.4 ; 1.9)\end{array}$ & $\begin{array}{c}1.7 \\
(1.5 ; 1.9)\end{array}$ & $\begin{array}{c}1.6 \\
(1.4 ; 2.2)\end{array}$ & $\mathrm{P}>0.05$ \\
\hline $\begin{array}{l}\mathrm{fT} 3, \\
\mathrm{pmol} / 1\end{array}$ & $\begin{array}{c}4.8 \\
(3.9 ; 5.6) \\
\end{array}$ & $\begin{array}{c}5.6 \\
(5.4 ; 5.8) \\
\end{array}$ & $\begin{array}{c}5.9 \\
(5.4 ; 6.3) \\
\end{array}$ & $\begin{array}{c}4.3 \\
(3.9 ; 4.7) \\
\end{array}$ & $\begin{array}{c}5.4 \\
(5.2 ; 5.6) \\
\end{array}$ & $\begin{aligned} & 5.5 \\
&(5.1 ; 5.9) \\
&\end{aligned}$ & $\begin{array}{l}\mathrm{P}_{1-2}=0.002 ; \mathrm{P}_{1-3}=0.002 \\
\mathrm{P}_{45}<0.001 ; \mathrm{P}_{46}<0.001\end{array}$ \\
\hline $\begin{array}{l}\mathrm{cAMP}, \\
\mathrm{nmol} / 1\end{array}$ & $\begin{array}{c}14.5 \\
(11.8 ; 43.1)\end{array}$ & $\begin{array}{c}22.1 \\
(20.3 ; 23.9)\end{array}$ & $\begin{array}{c}24.1 \\
(19.0 ; 28.8)\end{array}$ & $\begin{array}{c}15.3 \\
(12.5 ; 19.4)\end{array}$ & $\begin{array}{c}21.5 \\
(18.4 ; 23.9)\end{array}$ & $\begin{array}{c}22.6 \\
(12.1 ; 30.4)\end{array}$ & $\begin{array}{l}\mathrm{P}_{1-2}=0.049 ; \mathrm{P}_{1-3}=0.048 \\
\mathrm{P}_{45}<0.001 ; \mathrm{P}_{46}=0.026\end{array}$ \\
\hline fT3/fT4 & $\begin{array}{c}16.7 \\
(8.3 ; 19.6)\end{array}$ & $\begin{array}{c}10.8 \\
(7.5 ; 10.8)\end{array}$ & $\begin{array}{c}12.5 \\
(6.8 ; 13.4)\end{array}$ & $\begin{array}{c}12.4 \\
(8.0 ; 15.9)\end{array}$ & $\begin{array}{c}7.9 \\
(6.3 ; 8.4)\end{array}$ & $\begin{array}{c}8.2 \\
(7.4 ; 14.9)\end{array}$ & $\mathrm{P}_{45}=0.020$ \\
\hline$\frac{(\mathrm{fT} 3+\mathrm{fT} 4)}{\mathrm{TSH}}$ & $\begin{array}{c}0.27 \\
(0.25 ; 0.37) \\
\end{array}$ & $\begin{array}{c}0.39 \\
(0.36 ; 0.39) \\
\end{array}$ & $\begin{array}{c}0.51 \\
(0.35 ; 0.51) \\
\end{array}$ & $\begin{array}{c}0.27 \\
(0.24 ; 0.29) \\
\end{array}$ & $\begin{array}{c}0.39 \\
(0.37 ; 0.41) \\
\end{array}$ & $\begin{array}{c}0.41 \\
(0.36 ; 0.44) \\
\end{array}$ & $\begin{array}{l}\mathrm{P}_{1-2 ; 45446}<0.001 \\
\mathrm{P}_{1-3}=0.004 ; \mathrm{P}_{2-3}=0.04\end{array}$ \\
\hline
\end{tabular}

\section{Discussion}

Previous research has shown substantial seasonal changes in thyroid hormone activity among residents and sojourners to high latitudes. ${ }^{(11)}$ In a series of studies among sojourners to Antarctica, Reed et al. ${ }^{(12-14)}$ identified a constellation of physiological changes in response to severe cold exposure and reduced photoperiod. This cluster of responses, known as the "polar T3 syndrome," is associated with increased rates of production and clearance of T3, the active form of thyroid hormone, and T4, generally leading to reduced circulating levels of fT3 and fT4. ${ }^{(13-15)}$ N.V. Do et al. ${ }^{(16)}$ demonstrated that the adaptive changes in thyroid hormone economy with Antarctic residence reflect TSH dependent changes in thyroid synthetic activity, which may help explain a portion of the increases in T3 production found with Antarctic residence.

Research conducted in northern Europe, however, documents greater variability in seasonal changes in thyroid function, demonstrating both winter increases and decreases in fT3 and fT4. ${ }^{(17-18)}$ Levy et al. ${ }^{(11)}$ showed that the indigenous Yakut of northeastern Siberia experience marked seasonal changes in thyroid function. The marked declines in both fT3 and fT4 in Yakut men and women suggest an enhanced capacity to increase metabolic heat production during the severe winter cold.

Dopamine, a potent regulator of TSH secretion, can suppress TSH secretion in vivo ${ }^{(19)}$ and in vitro. ${ }^{(20,21)}$ The numerous studies show that the levels of thyroid hormones follow dopamine levels. ${ }^{(22,23)}$

The results of our study indicate parallel changes in the blood levels of dopamine and HPTA hormones in healthy people living in the Arctic territories. The absence of the inhibitory effect of high levels of dopamine on HPTA hormones in the examined individuals may be a compensatory-adaptive response of the body under the conditions of permanently acting extreme factors of the North.

Analysis of iodothyronines, their ratios and $\mathrm{TSH}$ in individuals with different blood levels of dopamine showed that in both men and women the most critical factor for thyroid activity and peripheral conversion of iodothyronines is undetectable levels of dopamine, which is confirmed by low cAMP levels, indicating a slowing down of the intracellular processes of synthesis of biologically active substances. It can be concluded that undetectable levels of dopamine in peripheral blood correlates with a lower activity of HPTA and peripheral conversion of iodothyronines, which can be an indicator of metabolic disturbances and a decline in overall well-being in conditions of iodine deficiency in the diet. Thus, the high frequency of undetectable blood dopamine levels among the female population may be a criterion for the risk of developing various somatic and psychological disorders.

Higher values of iodothyronines, cAMP and fT3/fT4 ratio in individuals with reference blood dopamine levels, compared with those with undetectable levels, may indicate 
the stimulating effects of dopamine on the HPTA activity ${ }^{(24)}$ and peripheral conversion of iodothyronines ${ }^{(25)}$ at the reference dopamine values. MJ Obregon and colleagues ${ }^{(25)}$ studied the direct effects of catecholamines on the activity of the type II iodothyronine 5 '-deiodinase in dispersed rat brown adipocytes. Incubation with norepinephrine or phenylephrine for 3-4 h causes up to a 5-fold increase in deiodinase activity in these cells. At the same time, higher TSH levels in people with reference dopamine levels may be due to the adverse climatic factors causing both the activation of the sympathoadrenal system and the increased HPTA activity. ${ }^{(1,26)}$

In addition, there may be an opposite effect associated with the stimulation of synthesis and secretion of catecholamines by thyroid gland hormones. ${ }^{(27)}$ It should be noted that increased levels of dopamine in the identified ranges, as well as its reference values, are associated with activation of HTPA, namely, an increase in T4 production and its conversion to more biologically active fT3, compared with the undetectable values of dopamine. Increased cAMP levels may also be an indirect sign of the activation of intracellular mechanisms by dopamine or TSH. ${ }^{(28)}$

Thus, the example of healthy individuals born and permanently residing in the territories of the Russian Arctic zone, regardless of gender, shows an increase in the activity of HTPA with an increase in the blood level of dopamine. In individuals with undetectable dopamine values, there is a decrease in the activity of HTPA and the peripheral conversion of iodothyronines compared with persons with reference or increased dopamine levels. The absence of the inhibitory effect of high levels of dopamine on HPTA hormones in the examined individuals may be a compensatory-adaptive response of the body under the conditions of permanently acting extreme factors of the North.

\section{Competing Interests} interests.

The authors declare that they have no competing

\section{Sources of Funding}

The reported study was funded by the FCIARctic according to the research project: "Elucidation of the modulating effect of the catecholamine levels on the hormonal profile in humans and aquatic organisms of the European North" (AAAA-A15-115122810188-4) and supported by the Russian Foundation for Basic Research (Grant № 18-010-00875).

\section{References}

1. Maslov LN, Vychuzhanova EA. The role of the sympathoadrenal system in adaptation to cold. Neurosci Behav Physiol. 2016;46(5):589-600. doi: 10.1007/s11055016-0283-0.

2. Harinath K, Malhotra AS. Pal K, Prasad R, Kumar R, Sawhney RC. Autonomic nervous system and adrenal response to cold in man at Antarctica. Wilderness Environ Med. 2005;16(2):81-91.
3. Tsirkin VI, Bagaev VI, Bein BI. [Role of Dopamine in Brain Activity (Literature Review)]. Vyatskii Med Vestnik. 2010;(1):7-18. [Article in Russian].

4. Sapronov NS, Masalova OO. [Neurophysiological effects of thyroid hormones. Psychopharmacol]. Biol. Narcol. 2007;7(2):1533-1541. [Article in Russian].

5. Haugen BR. Drugs that suppress TSH or cause central hypothyroidism. Best Pract Res Clin Endocrinol Metab. 2009;23(6):793-800. doi:10.1016/j.beem.2009.08.003.

6. Pereira JC Jr, Pradella-Hallinan M, Lins Pessoa Hd. Imbalance between thyroid hormones and the dopaminergic system might be central to the pathophysiology of restless legs syndrome: a hypothesis. Clinics (Sao Paulo). 2010;65(5):54854. doi: 10.1590/S1807-59322010000500013.

7. Lychkova AE. [Nervous regulation of thyroid function]. Vestn Ross Akad Med Nauk. 2013;(6):49-55. [Article in Russian].

8. Smelova IV, Golovneva ES. [Dynamics of functional activity of thyrocytes in the setting of changing morphofunctional activity of mast cells of the thyroid gland upon infrared laser therapy]. Bulletin of RSMU. 2016;(6):3944. [Article in Russian].

9. Melander A. Aminergic regulation of thyroid activity: Importance of the sympathetic innervation and of the mass cells of the thyroid gland. Acta Med Scand. 1977;201(4):25762. doi: 10.1111/j.0954-6820.1977.tb15696.x.

10. Tipisova EV, Kipriyanova KE, Gorenko IN, Lobanov AA, Popov AI, Andronov SV, et al. [The content of dopamine and hormones of system "hypophysis-thyroid" in blood of nomadic, settled and local population of the Arctic]. Russian Clinical Laboratory Diagnostics. 2017;62(5):52-56. doi: 10.18821/08692084-2017-62-5-291-296. [Article in Russian].

11. Levy SB, Leonard WR, Tarskaia LA, Klimova TM, Fedorova VI, Baltakhinova ME, et al. Seasonal and socioeconomic influences on thyroid function among the Yakut (Sakha) of Eastern Siberia. Am J Hum Biol. 2013;25(6):81420. doi: 10.1002/ajhb.22457. Epub 2013 Oct 15.

12. Reed HL, Burman KD, Shakir KM, O'Brian JT. Alterations in the hypothalamic-pituitary-thyroid axis after prolonged residence in Antarctica. Clin Endocrinol (Oxf). 1986;25(1):55-65.

13. Reed HL, Brice D, Shakir KM, Burman KD, D'Alesandro MM, O'Brian JT. Decreased free fraction of thyroid hormones after prolonged Antarctic residence. J Appl Physiol. 1990; 69(4):1467-72.

14. Reed HL, Silverman ED, Shakir KM, Dons R, Burman $\mathrm{KD}$, O'Brian JT. Changes in serum triiodothyronine (T3) kinetics after prolonged Antarctic residence: the polar T3 syndrome. J Clin Endocrinol Metab. 1990;70(4):965-74.

15. Harford RR, Reed HL, Morris MT, Sapien IE, Warden $\mathrm{R}, \mathrm{D}$ 'Alesandro MM. Relationship between changes in serum thyrotropin and total and lipoprotein cholesterol with prolonged Antarctic residence. Metabolism. 1993 Sep;42(9):1159-63.

16. Do NV, Mino L, Merriam GR, LeMar H, Case HS, Palinkas LA, Reedy K, Reed HL. Elevation in serum thyroglobulin during prolonged Antarctic residence: effect of thyroxine supplement in the polar 3,5,3'-triiodothyronine syndrome. J Clin Endocrinol Metab. 2004;89(4):1529-33.

17. Hassi J1, Sikkilä K, Ruokonen A, Leppäluoto J.The pituitary-thyroid axis in healthy men living under subarctic climatological conditions. J Endocrinol. 2001;169(1):195-203. 18. Plasqui G, Kester AD, Westerterp KR. Seasonal variation in sleeping metabolic rate, thyroid activity, and leptin. Am J 
Physiol Endocrinol Metab. 2003 Aug;285(2):E338-43.

19. Kaptein EM, Kletzky OA, Spencer CA, Nicoloff JT. Effects of prolonged dopamine infusion on anterior pituitary function in normal males. J Clin Endocrinol Metab. 1980;51(3):488-91.

20. Shupnik MA, Greenspan SL, Ridgway EC. Transcriptional regulation of thyrotropin subunit genes by thyrotropinreleasing hormone and dopamine in pituitary cell culture. J Biol Chem. 1986;261(27):12675-9.

21. Greenspan SL, Shupnik MA, Klibanski A, Ridgway EC Divergent dopaminergic regulation of $\mathrm{TSH}$, free alphasubunit, and TSH-beta in pituitary cell culture. Metabolism. 1986;35(9):843-6.

22. Feek CM, Sawers JS, Brown NS, Seth J, Irvine WJ, Toft AD. Influence of thyroid status on dopaminergic inhibition of thyrotropin and prolactin secretion: evidence for an additional feedback mechanism in the control of thyroid hormone secretion.J Clin Endocrinol Metab. 1980;51(3):585-9.

23. Scanlon MF, Weetman AP, Lewis M, Pourmand M, Rodriguez-Arnao MD, Weightman DR, Hall R. Dopaminergic modulation of circadian thyrotropin rhythms and thyroid hormone levels in euthyroid subjects. J Clin Endocrinol Metab. 1980;51(6):1251-6.

24. Melander A, Sundler F, Westgern U. Intrathyroidal amines and the synthesis of thyroid hormone. Endocrinology. 1973;93(1):193-200. doi: 10.1210/endo-93-1-193.

25. Obregon MJ, Mills I, Silva JE, Larsen PR. Catecholamine stimulation of iodothyronine $5^{\prime}$-deiodinase activity in rat dispersed brown adipocytes Endocrinology. 1987;120(3):106972. doi: 10.1210/endo-120-3-1069

26. Burger AG. Environment and thyroid function. J Clin Endocrinol Metab. 2004;89(4):1526-8. doi: 10.1210/jc.20040332

27. Santos NC, Costa P, Ruano D, Macedo A, Soares MJ, Valente J, et al. Revisiting thyroid hormones in schizophrenia. J Thyroid Res. 2012;2012:569147. doi: 10.1155/2012/569147. 28. Toccafondi R, Rotella CM, Tanini A, Aterini S, Borrelli D, Loddi L, Arcangeli P. Effects of TSH on cAMP levels and thyroid hormone release in human thyroid 'autonomous' nodules: relationship with iodothyronine and iodine content in thyroglobulin. Clin Endocrinol (Oxf). 1982;17(6):537-546. doi: 10.1111/j.1365-2265.1982.tb01626.x. 